\title{
THE DEVELOPMENT OF FUNDAMENTAL MOVEMENT-BASED LEARNING USING WATER GAMES FOR CHILDREN 5 - 6 YEARS
}

\author{
Rizki Kurniati \\ Coaching Indonesian Community University of Medan \\ Kyereen19@gmail.com
}

\begin{abstract}
The purpose of this research are; (1) develop fundamental movement based learning using water games for children 5-6 years and (2) obtain empirical data on the effectiveness of the results of model development fundamental movement based learning using water games for children aged 5-6 years. Subjects in this study were children aged 5-6 years in kindergarten. Place of research conducted in the city of Palembang. This study is the development of the Research and Development of Borg and Gall. Product results of the research is a fundamental movement guidebook using water games. Research shows that: (1) the development of fundamental movement based learning using water games for children aged 5-6 years have been declared invalid by a motor learning, physical activity experts and practitioners of early childhood education, (2) fundamental movement based learning using water games proved $85 \%$ can improve fundamental skills and helps to build a sense of confidence and courage.
\end{abstract}

Keywords: fundamental movement, water games, children aged 5-6 years.

Water activity is given before the child learns swimming techniques. Aquatic activities in water recognition include baseline motion, attitude, and water security to prepare children to learn swimming techniques. The basic motion in question is the foundation for swimming, which consists of the way into water, the buoyancy of the body in water, the movement of the legs, the balance of the body in water, the motion of the arms, and the control of the breath. The basic attitudes established through water recognition activities are courage, obey rules, and active participation.

Many cases occur in swimming pools such as drowning, which causes children to feel afraid to do water activities. According to the US Healthy and Safety executive (2015: 124), drowning in a swimming pool is one of the leading causes of death for children aged 14 years. By 2015, the Association of US Swimming Schools noted, from May to September alone there were 209 cases of children drowning in pools and 76 on the lake.

The basic understanding that children are expected to achieve through water recognition activities is understanding of classroom procedures, swimming pool rules, game rules, teacher instruction, and basic movement exercises.

Water activity through swimming has become a program in several kindergartens. Implementation of learning using the school's swimming pool for kindergarten who has swimming pool facilities. Kindergarten that does not have swimming pool at certain period of time rent public swimming pool. This indicates that both kindergarten teachers and parents are aware of the need to introduce students to the water play environment. When the 
researcher interviewed one of the kindergarten teachers there was a statement, "The game in the water required the child to train self-confidence, besides the child can play fun". Master feels the need to organize a water play activity on the students to stimulate confidence, courage, balance and emotional social development.

The development of the basic motion learning model is complemented by safety rules to introduce children to how to safely play in water. The model that has been developed is expected to provide a reference for teachers about the variation of the water recognition model so as to make it easier for the teacher to apply the basic motion learning model based on the game. Teachers are expected to organize models in teaching and learning activities so that all children have a safe experience playing in the water.

The concept of model development is an idea of the development process to produce something. Tangkudung concept developed model that is the basic concept of a researcher to underlie the development of the model to be done (Tangkudung, 2016; 11). In this research and development, the idea to be created or produced is a book, which is further termed the basic motion-based motion development model. The basic motion-based motion development model is games that must be arranged in a sequence according to the needs of the child, as well as the pattern of child development.

By combining two movements or more basic movements such as walking, running, throwing, jumping, and swing aimed at the child's motor skills. Development of motor skills in children aged 5-6 Years through physical activity, such as running, jumping, throwing and other play activities that use large and small muscles.

Physical-motor learning as one stimulus to the child so that children can move actively based on age and stage of development. Stimulation of growth and development in children aged 5-6 years can be done by playing. The concept of game children aged 5-6 years applied to the concept of the game that gives the opportunity for children to move freely. The concept of the development of a basic movement based learning on water games is to use water as one of the tools in the game process.

Water is used as a good medium in stimulating the child's development both in establishing confidence, motor skills, hand eye coordination, and improving fitness. The concept of developing this model is to use simple tools, which are available in the neighborhood. For example the use of balloons, bottles, basins, buoys, sponge, flags, and other tools that can be utilized as equipment, then combined with games to be developed.

Fundamental motion is the basis of human movement that continues to grow in accordance with the growth, experience, adaptation and maturity of an individual. Gallahue's opinion states that basic motion skills, ie (Magill, 2011; 3). Total body movement in wich the body is propelled in an upright posture from one point to the onother in a roughly horizontal or vertical direction, movement such walking, running, hopping, galloping, leaping, sliding and jumping.

According to Magil, motor learning is a study of motor skills, improving the performance of learning motor skills to improve movement experience, or recovering skills 
that are difficult to do or can not be done because of injury, illness and the like. What is interesting is the behavioral and / or neurological changes that occur to a person while learning the motor skills and other variables that influence the change (Gallahue\&Ozmun, 2006; 13).

Motor learning process that occurs, among others: (1) the stage of receiving and processing input, (2) control and decision processes, and (3) performance of motor skills. The gradual expression of motion will increase in effectiveness and stability if it continues to be trained with appropriate frequency, intensity, and tempo. The final stage of the motor learning process is the autonomy stage. Characteristic of the stage of autonomy, which is already established automatic motion because the perpetrator of motion has mastered the skills of motion. Thought the sequence of motion yag must be done is not needed so that actors can accept other tasks. Motion skills still have the possibility to be improved. Exercises are still needed at the autonomy stage to improve the quality of motion.

Schmidt \& Wrisberg $(2004 ; 126)$ referred to this stage of motor learning as cognitive because conscious mental processes dominate early in learning. In this stage, learners are almost totally dependent on declarative memory, and information is consciously manipulated and rehearsed in formulating motor commands. Learners quite literally attempt to "think" their way through the performance of skills in this stage.

Sport New Zealand $(2012 ; 34)$ This resource groups skills and activities under three fundamental movement skill categories:

1) Locomotor skills involve the body moving in any direction from one point to another.Locomotor skills in this resource include walking, running, dodging, jumping, hopping and skipping.

2) Stability skills involve the body balancing either in one place (static) or while in motion (dynamic). Stability skills in this resource include landing, balance (static and dynamic) and rotation.

3) Manipulative skills involve handling and controlling objects with the hand, the foot or an implement (stick, bat or racquet). Manipulative skills in this resource include throwing and catching, striking with the hands, feet and an implement (e.g. kicking, volleying, batting and dribbling)."

Thus it can be concluded that the basic motion consists of locomotor, non lokomotor, and manipulative.

Kindergarten learning is essentially play-oriented learning (learning while playing and playing while learning), development-oriented learning that gives more opportunities for children to learn in the right ways. The most appropriate approach is child-centered learning.

According to Sukadiyanto (2011: 130) the world of children is a world of play, meaning all kinds of activities devoted to the development of potential early childhood means used through play. In general, play activities always involves physical activity. For that 
teachers need to know about the principles of physical learning (motor) which is generally done through play.

It can be concluded that play has many functions in the development of children. The function of play can not only improve cognitive and social development, but the development of language, discipline, moral development, creativity and physical development of children.

Every child loves water, one example is swimming. One of the most important skills can be instilled in children from an early age. Playing activities done in the water can increase the confidence of children indirectly can train children in reducing fear. Before entering on the game of water games, children aged 5-6 years must be introduced with the introduction of water. This is so that children can easily adapt to the aquatic environment.

Susan (2007: 04) water learning is based on the idea that interaction with water can both stimulate and enhance a child's growth and development. Water learning uses activities in a aquatic environment to enrich and reinforce learning in nonaquatic areas of child development. Water learning is use primarily reinforce academics. However, water learning can also reinforce motor skills, physical fitness, perceptual motor development, and sport skill.

Water play provides social benefits. Learning new games develop children's listening skills and cognitive development. The game also provides a positive environment in helping children and even shy children, as well as improving interpersonal children. Successfully interacting with others helps children gain confidence. In addition games that require children to use their imagination encourage participants to express ideas and share creativity with others.

The fundamental thing in the activity of learning water activities in order to avoid accidents so prevention efforts, vigilance and anticipation should be emphasized in learning in children especially those under 5 years old. This should be emphasized to the child, whether before being in the water or even while in the water. American Red Cross (2014: 16) Water safety is a combination of attitude, knowledge, practice and skills. A Water Safety instructor, you have a responsibility to teach participants of all ages what it takes to be safe in, on and around the water, and to always promote a "safety-first" attitude.

According to Dorset County Council (2012: 10) there are several important points that are the responsibility of the teacher, namely; (1) the teacher should notify you that you should not run by the pool, (2) give instructions in and out of the pool, (3) supervise the children, in case of a hazard immediately signaled. And Peter \& Sarie (2005: 345) Water safety that need to be considered in the safety in the pool ie;

1. Doing Heating and Cooling before and after the game.

2. Pool water depth $70 \mathrm{~cm}$.

3. Clean water so that the bottom of the pond can be seen from the water surface.

4. Water temperature between 30-34 C, while the air temperature is $2 \mathrm{C}$ above the water temperature.

5. The content of chlorine in water is ideal $\mathrm{Cl}$ of $1.0-1.5$ and ideal $\mathrm{pH}$ of 7.4-7.8. 
6. The tile / ceramic bottom of the pond is not loose and there are no holes.

7. Pool size $6 \times 8 \mathrm{~m}$ can be used for 20 students.

8. Equipment: Material does not contain toxic, Color does not fade in water and Surface equipment does not potentially injure the skin.

Sport England Health and Safety Commission (2006: 179), safety equipment can be; (1) Buoys (can be tire or shaped), serves to help the rescue in the pond. In addition, it can help the learning process of students while in the pool. (2) Mask or goggles (glasses), serves to protect the eyes from getting exposed to water, (3) Buoy the rope legs (deep-float), serves to keep the position of the foot to stay above the water surface.

Therefore, safety equipment and equipment is needed in the learning process in water. It aims to minimize accidents that may occur. In addition, the role of teachers and instructors in the learning process that will take place. So that unwanted accidents can be prevented by procedures and tools that have been supported.

\section{METHOD}

The design of this study researchers refers to the development model (research and development) Borg and Gall. Of the ten steps there are some modified by the researchers as needed. Measures taken Steps taken (1) Needs analysis and field observation, (2) Prepared Research Plan, (3) Early product development, (4) Trial, (5) Initial product revision, (6) ) Main field test (7) Product revision (8) Main test to see results of product effectiveness, (9) Final revision and (10) Dissemination and implementation. The subjects of this study were 6 Kindergarten students taken using random sampling technique. The type of data produced in the form of quantitative data and qualitative data. The qualitative data is derived from the results data from expert suggestions and inputs. Quantitative data use descriptive quantitative analysis technique with percentage and statistic Test $\mathrm{T}$ on product effectiveness test. The subjects involved in this development are as follows: (1) the subject as a preliminary study (needs analysis) interviewed 15 teachers from three schools, (2) expert evaluation subjects consisting of 2 motor experts, 3) The test subjects were 20 children from Amalia kindergarten, (4) The field trial subjects were 60 children from two schools, Mahardika and PAUD Mandiri (5) main test subjects on the effectiveness test were 80 children from three schools, TK Pembina, TK Ar-Raiha, and Early Childhood Education School. In the test effectiveness test used is the fundamental movement assessment.

\section{RESULT}

The study was conducted in kindergarten by involving teachers and children aged 5-6 years as a place of model development. Initial activities undertaken by researchers to obtain results that really can answer the problem of research is to conduct analysis kebutuahan. The researcher conducts the initial research or needs analysis undertaken. From the results of observations and interviews it can be seen that; At the time of the interview, the researcher asked the class teacher's response when a model of water introduction was introduced in the classroom as a teacher. There are two kinds of answers from a total of 15 teachers from three schools, namely; Agree and disagree. (1) first answer disagreed given by 3 teachers (20\%), 
while 12 teachers (80\%) answered agree. The third reason the teachers disagree because the teacher does not have swimming skills and has never done motor learning in the pool. After performing the data collection and drafting phase of the learning model, the next step is to perform expert test. The purpose of this expert review is to obtain the feasibility or validity of the model, the accuracy and suitability of the product developed with the needs in the field. Expert opinions are collected by using a questionnaire containing questions and suggestions. Based on expert test conducted can be concluded that the variation of basic motion-based learning model of water game is feasible and can be used and produce 28 variations of learning model.

Furthermore after 28 models revised from the expert then proceed with a small test is limited by using the subject of research as many as 20 children who come from kindergarten in the city of Palembang Based on the evaluation of limited trials conducted can be concluded: 1) the preparation of difficulty level begins from the movement And games from the easy to the tough, from light to heavy, and simple to the complex. 2) optimization of implementation time and security. 3) the number of basic moves to 58 movements and 28 games that the child can do. The next step after 28 games revised from the experts then proceed with the main test using the subject of research as many as 60 children from Kindergarten. In the opinion of the experts on the development of learning models that have been tested in the field testing, it turns out that the use of models that have been developed there is no need to be revised because all aspects already meet the standards to be used so that it can be carried out product testing by testing the effectiveness and Efficiency in the learning process. Next steps The operational trials (effectiveness test) of this test involve a wider audience. The main purpose of this step is: how effective the results of application of the model design to the purpose of research. Research at this stage uses a quantitative approach, with a pre-experimental research design in the form of the one group pretest-postest design.

Tabel 1. Design Research in the Model Effectiveness Test

\begin{tabular}{llll}
\hline Subyek & Pre-test & treatment & Post-test \\
\hline $\mathrm{R}$ & $\mathrm{O}_{1}$ & $\mathrm{P}$ & $\mathrm{O}_{2}$ \\
\hline
\end{tabular}

The results of model effectiveness test conducted in this research is to perform performance tests on 4 schools, namely: TK AR-Raihan, TK Negeri Pembina, and PAUD Tunas Pertiwi, totaling 80 children were given treatment by using the basic motion-based learning model Water for children 5-6 years. Given for 5 five meetings. The following are the results of the model's effectiveness test:

Tabel 2. Paired Samples Statistics Pretest dan Posttest

\begin{tabular}{|l|l|l|l|l|l|l|}
\hline & & & & & Std. Error & \\
\hline \multirow{2}{*}{ Pair 1 } & Pretest & 7.2850 & 80 & 6.76676 & .66992 & $15 \%$ \\
\cline { 2 - 7 } & Postest & 9.5750 & 80 & 8.25204 & .83042 & $85 \%$ \\
\hline
\end{tabular}


Based on the above table that the average score of test scores based on observations before the basic learning model based on water games for children aged 5-6 years is 7.2850 before the postest and after being given treatment to 9.5750 increase. Percentage before treatment $15 \%$ (12 children) who can take the test, while after treatment $85 \%$ ( 68 children) who successfully take the test. This proves that the fundamental movement-based learning model of water game can approach the predetermined target and the goal of this water game is achieved.

Tabel 3. Hasil Paired Samples Test Pre Test dan Post Tes

Paired Samples Test

\begin{tabular}{|c|c|c|c|c|c|c|c|c|}
\hline & \multicolumn{5}{|c|}{ Paired Differences } & \multirow{3}{*}{ 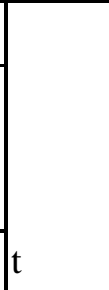 } & \multirow[b]{3}{*}{ df } & \multirow{3}{*}{$\begin{array}{l}\text { Sig. (2- } \\
\text { tailed) }\end{array}$} \\
\hline & \multirow[b]{2}{*}{ Mean } & \multirow{2}{*}{$\begin{array}{l}\text { Std. } \\
\text { Deviation }\end{array}$} & \multirow{2}{*}{$\begin{array}{l}\text { Std. } \\
\text { Error } \\
\text { Mean }\end{array}$} & $\begin{array}{l}95 \% \\
\text { Interval } \\
\text { Differenc }\end{array}$ & $\begin{array}{l}\text { Confidence } \\
\text { of the }\end{array}$ & & & \\
\hline & & & & Lower & Upper & & & \\
\hline $\begin{array}{ll}\text { Pair } & \text { Pretest } \\
1 & \text { Postest }\end{array}$ & $\begin{array}{l}3.8500 \\
0\end{array}$ & 5.67502 & .76602 & 1.36125 & 4.33875 & 6.872 & 79 & .000 \\
\hline
\end{tabular}

In test of significance of difference by using SPSS obtained Mean $=3,850$ show difference of pretest and posttest, result t-count $=6,872, \mathrm{df}=79$ and $\mathrm{p}$-value $=0.00<0.05$ meaning there is significant difference between before and after existence of treatment model of learning fundamental movement based water game.

\section{CONCLUSIONS}

Based on the results of field trials and discussion of research results of fundamental movement-based learning using water games for children $5-6$ years, it can be concluded that: This research has produced a book product in the form of fundamental movement-based learning using water games for children $5-6$ years. Based on the results of the effectiveness test of the fundamental movement based learning on water games, it is evident that the product yield has a very good effectiveness after the treatment. This can be seen from the percentage of success of $85 \%$ means that 68 children successfully in the tests given. It can also be shown with t-test results showing a very significant increase. So, the fundamental movement-based learning using water games for children $5-6$ years effective to achieve goals.

\section{REFERENCE}


American Red Cross. "Water Safety Instructur Manual." USA: KramesStaywell Strategic, 2014.

Dorset County Council. "Swimming Pool Safety." England; Dorset Publish, 2012.

Gallahue \& Ozmun. Understanding Motor Development, $6^{\text {th }}$ ed. New York: Mc Graw Hill, 2006

Health and Safety Executive. Safety in Swimming Pool. .England; Sport England Publication, 2015.

James Tangkudung. Macam-Macam Metodologi Penelitian Uraian dan Contohnya. Jakarta: Lensa Media Pustaka Idonesia, 2016.

J Susan Grosse, Water learning. United State: Human Kinetics, 2007.

Richard A. Magill, Motor Learning and Control concepts and application (9thed). NewYork: McGraw-Hill, 2011.

Meaney, Peter \& Culka, Sarie. Wet Games: a fun approach to teaching swimming and water safety. Wellington St Clifton Hill, Victoria Australia; 2005.

Sukadiyanto. "Pengantar Teori dan Metodologi Melatih Fisik," Yogyakarta:FIK Uiversitas Negeri Yogyakart, 2011.

Sport New Zealand. Fundamental Movement Skills among children in New Zealand. Wellington: Sport New Zealand, 2012.

Sport England \& Health and Safety Commission. Managing health and safety in swimming pools, 3rd ed, Sudbury, Suffolk, UK, HSE Books. 2006,

Schmidt \& Wrisberg, Motor learning and performance ( $3^{\text {rd }}$ ed), Los Angeles: Huaman Kinetics, 2004. 